\title{
Back to the future
}

\author{
Contemporary biopolitics in 1920s' British futurism
}

\author{
James J. Hughes
}

B ioethicists mistakenly think that the current debate about the potential for human evolution and enhancement through nanotechnology, genetics and psychopharmacology has only been considered in speculative fiction. In fact, the debate about biofuturism is much older: it began 300 years ago with the speculations of Denis Diderot (17131784) and Nicolas de Caritat, the Marquis de Condorcet (1743-1794), and continued to evolve until the present day (Paul, 2004). These men, and other philosophers of the Enlightenment, first pondered the possibility of using knowledge and rational thinking to improve humankind as well as individual humans.

\section{These early biofuturist speculations, and the debates that they generated, anticipated modern debates on posthumanity and transhumanism...}

However, it was in the English-speaking world of the early twentieth century when more far-reaching speculations-largely the science fiction of Herbert George Wells (1866-1946), Olaf Stapledon (18861950) and Aldous Huxley (1894-1963)triggered an earnest debate about the use of science to shape human evolution. These fictional works were, in turn, inspired and motivated by the essays of John Burdon Sanderson Haldane (1892-1964), John Desmond Bernal (1901-1971), and the radical, political and scientific milieu in 1920s' England. These early biofuturist speculations, and the debates that they generated, anticipated modern debates on posthumanity and transhumanism, with left-wing and right-wing Utopians on one side, and left-wing, humanist and religious opponents of a posthuman future on the other. The contours of the debate in the 1920s-among partisans of the Enlightenment and its critics-are still shaping our approaches to political and ethical issues ranging from abortion and cloning to nano-pollution, genetically modified food and performance-enhancing drugs.

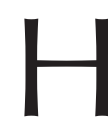
aldane was one of the most important scientists and popularizers of science in the first half of the twentieth century. His father was a professor of physiology at Oxford University in the UK in the late 1800s, and it was assumed that Haldane would follow in his footsteps. By the age of 22, Haldane had earned a degree in classics and was already a respected biological researcher at Oxford University. Then the First World War began, and he was sent to serve as a bombing officer in France and Iraq.

His military experiences left Haldane profoundly disillusioned, and he became convinced that human beings must use science and reason to improve every aspect of human life. He later commented that, "the scientific point of view must come out of the laboratory and be applied to the events of daily life. It is foolish to think that the outlook which has already revolutionized industry, agriculture, war and medicine will prove useless when applied to the family, the nation, or the human race" (Haldane, 1933). After he returned to England in 1919 and took up a biology lectureship at Cambridge University, Haldane had become both a socialist and a dedicated evangelist for the possibilities of improving humanity through practical applications of the new research field of genetics.

\section{...while science might have potential for both good and evil, our hope lies in using it to reshape our 'human nature' for the better}

In 1923, Haldane gave a talk to the 'Heretics Club' at Cambridge University titled, Daedalus or Science and the Future, which was subsequently published, and triggered an intense debate of his ideas. The title of his speech and the essay actually hinted at the importance of biology: according to Greek mythology, Daedalus was the king of Crete who bred a bull and a woman to make the Minotaur. Haldane began Daedalus by reflecting on the First World War, and speculating as to whether the progress of science would destroy humankind or perhaps reduce us to a machine-like existence, which would support 'the case against science'. "Has mankind released from the womb of matter a Demogorgon which is already beginning to turn against him, and may at any moment hurl him into the bottomless void?", he asked. "Or [might man become] a mere parasite of machinery, an appendage of the reproductive system of huge and complicated engines which will successively usurp his activities, and end by ousting him from the mastery of this planet?" (Haldane, 1924). Although science and technology do increase human powers for both good and evil, Haldane remained optimistic that such powers can be turned to the good to "bring mankind more and more together, to render life more and more complex, artificial and rich in possibilities." In his essay, he projected a prosperous future world society with clean and abundant energy, which would eventually be united under one government. 
Haldane argued that society initially despised biological innovators, such as the domesticators of plants and animals, but then later came to revere them. Haldane suggested that people who advocate 'ectogenesis' or extra-uterine gestation and the project of genetic enhancement would eventually meet the same revulsion, but that, 150 years hence, most babies will be 'conceived' by ectogenesis. This is actually a reasonable prediction in light of the increasing use of assisted reproductive technologies to conceive children, and the debate over pre-natal and pre-implantation diagnostics of genetic disorders.

$\mathrm{H}$ aldane also predicted a period of eugenics that would aim to control human reproduction to improve the health and abilities of the population-but that such eugenic policies would soon be made moot by direct genetic engineering and psychopharmacology. Yet, Haldane forcefully denounced the racist biases of eugenicists for the rest of his life, and insisted that the most effective policy for improving the genetic health of a population is to "force upon it the greatest practicable amount of liberty, education and wealth" (Haldane, 1927). He imagined a future democracy in which candidates for office would compete over who could make the next generation taller, healthier or smarter, or even over whether children should have prehensile tails.

\section{After allowing our conquest of nature and our bodies, science empowers humankind to subjugate the dark and evil elements of its own soul}

Haldane concluded that, while science might have potential for both good and evil, our hope lies in using it to reshape our 'human nature' for the better. After allowing our conquest of nature and our bodies, science empowers humankind to subjugate the dark and evil elements of its own soul. "As our knowledge of this subject increases we may be able, for example, to control our passions by some more direct method than fasting and flagellation, to stimulate our imagination by some reagent with less after-effects than alcohol, to deal with perverted instincts by physiology rather than prison."
How, then, can we trust that the powers to reshape human nature will be used to create better people? "It may be urged that they are only fit to be placed in the hands of a being who has learned to control himself, and that man armed with science is like a baby armed with a box of matches." Haldane acknowledged the risk of abuse, but pointed to the gradual progress against social evils, and the expectation that human beings will eventually outgrow nationalism and war. He argued that science is a catalyst for social progress, intensifying struggles for a better world: "Moral progress is so difficult that I think any developments are to be welcomed which present it as the naked alternative to destruction, no matter how horrible may be the stimulus which is necessary before man will take the moral step in question." The influential physicist Freeman Dyson summarized this perspective as follows: "The final message of Daedalus is that ordinary people can turn evil into good if they have the necessary courage and moral leadership" (Dyson, 1995).

A s mentioned above, the speech by Haldane triggered an intense debate on posthumanity and the role of science and technology in improving mankind. Within a year, the British philosopher Bertrand Russell (1872-1970) delivered a direct response to Daedalus titled, Icarus, or the Future of Science (Russell, 1924; Rubin, 2005), as part of a series of speeches sponsored by the Fabian Society under the title 'Is Civilization Decaying?' The arguments made by Russell reflected the tension within the Enlightenment tradition between optimism and pessimism about technology. For techno-optimists, such as Haldane, science, reason and technological progress were complements to social equality and individual liberty. For secular, left-wing pessimists, including Russell, science and technology would always add to the power of dominant classes and military machines.

Although an atheist, Russell expressed the fear shared by many religious opponents of human enhancement that technology empowers indulgence in vices, from sloth and gluttony to violence. "All that gives men power to indulge their collective passions is bad [...] Where [kindly impulses] exist, science helps them to be effective; where they are absent, science only makes men more cleverly diabolic" (Russell, 1924).

Moreover, Russell was not placated by Haldane's assertion that defects in human character could be fixed by science. Russell anticipated the Russian perversion of psychiatry as a tool of political repression when he suggested that governments would exploit the ability to control human personality and emotions. "The State could give to the children of holders of power the disposition required for command, and to the children of the proletariat the disposition required for obedience [...] We shall have the emotions desired by our rulers, and the chief business of elementary education will be to produce the desired disposition, no longer by punishment or moral precept, but by the far surer method of injection or diet."

\section{For secular, left-wing pessimists, including Russell, science and technology would always add to the power of dominant classes and military machines}

Although Russell welcomed the control of emotions to enhance virtuous impulses, such as kindliness, he saw little chance that the powers-that-be would apply such control beneficently. "Alas, the physiologists would first have to administer the lovephiltre to themselves before they would undertake such a task. Otherwise, they would prefer to win titles and fortunes by injecting military ferocity into recruits. And so we come back to the old dilemma: only kindliness can save the world, and even if we knew how to produce kindliness we should not do so unless we were already kindly."

A Idous Huxley was the brother of the biologist Julian Huxley, and both were friends of Haldane. Yet, where Julian enthusiastically endorsed the biofuturism of Haldane and went on to coin the term 'transhumanism' (Huxley, 1957), Aldous was repelled by it. In his Brave New World-a direct response to the ideas of Daedalus - Aldous depicted a future of controlled reproduction, genetic engineering, neurotechnology and a world socialist state as an alienated hell (Huxley, 1932).

The response to Brave New World reflected the polarization between technopessimists and -optimists (Nicol, 2007). Russell welcomed it, because the novel highlighted the deep-seated suspicion of engineered health and happiness, and of a well-ordered world. Russell acknowledged, however-as the defenders of the 'wisdom 


\title{
Science is as yet in its infancy,
}

and we can foretell little of the future

save that the thing that has not been is the thing that shall be;

that no beliefs, no values, no institutions

\author{
are safe.
}

J.B.S. HALDANE in

DAEDALUS OR SCIENCE AND THE FUTURE

A paper read to the Heretics, Cambridge, on February 4th, 1923

of repugnance' do today-that this 'yuck factor' is basically irrational: a desperate, although necessary, clinging to illusions. Although we object to the brainwashing techniques in Brave New World, all parenting and education are efforts to mould children: "we do not object to molding a human being, provided it is done badly; we only object when it is done well" (Nicol, 2007).

By contrast, Wells-a techno-optimist, although an author of both Utopian and dystopian futures-wrote that Brave New World had betrayed the future. Other critics called it an unforgivable offence to progress, reflecting the author's fear and hatred of modernity. Most telling perhaps is the observation by poet and novelist Leonard Alfred George Strong (1896-1958) that the Luddite Romanticism of its vision was a secular version of an older reactionary religious response to modernity, reduced to existential complaint by the postmodern condition: "Mr. Huxley has been born too late. Seventy years ago, the great powers of his mind would have been anchored to some mighty certitude, or to some equally mighty scientific denial of a certitude. Today he searches heaven and earth for a Commandment, but searches in vain: and the lack of it reduces him, metaphorically speaking, to a man standing beside a midden, shuddering and holding his nose" (Nicol, 2007).

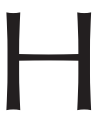

aldane wrote two more essays that can be regarded as sequels to Daedalus. The first was published in Harpers Magazine in 1927 as, The Last Judgment, a Scientist's Vision of the Future of Man (Haldane, 1927; Adams, 2000). Deeply influenced by the novels of Wells, Haldane argued that the further evolution of humanity will take place over millions of years, just as our evolution to this point took millions of years. He projected the creation of a united Utopian world, reshaped to satisfy human desires, over the next couple of million years. Disease is eliminated and average life expectancy is 3,000 years. Life is focused on friendships, music, art, eating, drinking and being merry.

Similarly to the lunar insectile Selenite society in the Wells' novel, First Men in the Moon (Wells, 1901), Haldane suggested that this Utopia would become stagnant. Our 'Lotus Eater' descendents would stop pursuing scientific discovery or space exploration. After 25 million years, people would even be indifferent to the impending destruction of all life on Earth owing to human exploitation of the rotation of the moon for energy. A hardy, genetically enhanced few would eventually begin the terraforming and colonization of Venus, where posthuman evolution would continue. The Venusians would enhance virtue and courage until they would again be "capable of self-transcendence", and would evolve beyond individualism into a dynamic social super-organism, which would set out to colonize the rest of the galaxy so that "all the matter in it available for life should be within the power of the heirs of the species whose original home has just been destroyed." Haldane concluded that these posthumans would evolve into "a new kind of being which will bear the same relation to mind as do mind to life and life to matter."

\section{Although we object to the brainwashing techniques in Brave New World, all parenting and education are efforts to mould children}

The Christian fantasist Clive Staples Lewis (1898-1963) commented that the "brilliant, though to my mind depraved" vision of human enhancement and defeating death in the Last Judgment was a threat to Christianity (Lewis, 1966; Adams, 2000; 
Green \& Hooper, 1974). Lewis responded with the Perelandra Trilogy, which comprised three science fiction novels set on Mars, Venus and Earth, and caricatured Haldane as the physicist Weston, who was possessed by Satan.

\section{Bernal was also widely influential as a socialist, who argued for using the liberating possibilities of science, which he believed capitalism was holding back}

At the other end of the spectrum was the philosopher Stapledon, who was immediately taken with the futurism in the Last Judgment, and wrote his own influential history of the next billions of years of human evolution: Last and First Men: A Story of the Near and Far Future (Stapledon, 1930). His work described 17 distinct posthuman species succeeding 'Homo sapiens 1.0', who drive themselves to near extinction in apocalyptic warfare over a 100,000-year span. Some of the posthuman varieties include winged species, dwarves, giants and brains without bodies.

$\square$ n 1929, inspired by Daedalus and Last Judgment, the Irish physicist Bernal wrote his own widely influential futurist essay, The World, the Flesh \& the Devil: An Enquiry into the Future of the Three Enemies of the Rational Soul (Bernal, 1929). Bernal had already had a deep impact on both the sciences and left-wing politics. After receiving his bachelor's degree in mathematics and science from Cambridge University in 1922, the 21-year-old Bernal began to work at the Davy-Faraday laboratory in London, UK, where he determined the structure of graphite in 1924. In the 1930s, he pioneered the use of X-rays to determine the structure of matter, thereby launching the field of microbiology. Rosalind Franklin, who first visualized the double-helix structure of DNA, studied the technique in the Bernal laboratory. When Bernal died in 1971, many Nobel laureates had been taught by him or influenced by his scientific work.

Bernal was also widely influential as a socialist, who argued for using the liberating possibilities of science, which he believed capitalism was holding back. The scientists and intellectuals who agreed with his ideas of a social mission for science, including
Haldane, became known as 'The Invisible College'. They organized the Association of Scientific Workers, and the Division for Social and International Relations of Science-a part of the British Association for the Advancement of Science. The 1939 essay Social Function of Science by Bernal is considered the first text on the sociology of science (Bernal, 1939).

In The World, the Flesh and the Devil, Bernal proposed that science would eventually allow humans to tame the world, the defects of the body (the flesh), and those of the mind (the devil). Conquering matter, he predicted, will eventually take humanity into space to colonize other planets. Like Haldane and Russell, Bernal also suggested that our growing understanding of psychology and the brain will allow us to unravel our psychological problems - although he was uncertain whether the path of mental health would lead to a static society of hedonists or to "more fully human and fully intellectual lives". Reflecting on the theory of the Austrian psychiatrist Sigmund Freud (1856-1939), he suggested that the sublimation of the sex drive into other activities could advance our intellectual life.

However, the essay by Bernal is best known for being the first explicit proposal of brain-computer interfaces and cyborgs. In the future, he wrote, humans would spend their first 120 years of life enjoying their organic bodies, until they reached sufficient maturity to transfer their brains to non-organic, cyborg bodies. Cyborg minds would be connected to each other through the 'ether' to form collectives capable of much more than isolated individuals. "Barriers would be down: feeling would truly communicate itself, memories would be held in common, and yet in all this, identity and continuity of individual development would not be lost." Eventually, he suggested, these cyborg 'hive' minds would evolve beyond bodies altogether.

\section{The Utopian biofuturism expressed in the writings of these British scientists, philosophers and authors is an inevitable product of the Enlightenment...}

Bernal also anticipated conservative revulsion of his posthuman vision. "We shall have very sane reactionaries at all periods warning us to remain in the natural and primitive state of humanity, which is usually the last stage but one in their cultural history. But the secondary consequences of what men have already done-the reactionaries as much as any-will carry them away then as now." Similarly, Bernal foresaw arguments against human enhancement on the grounds of equality, diversity or individuality. He admitted honestly that some people might become more enhanced than the rest, leading to a technocratic ruling class or even to the splitting of humanity into warring subspecies. Conversely, he acknowledged that the collective minds might, like businesses, have a tendency towards monopoly and eventually fuse into one big mind. Whatever the end, it is in the hands of humanity to decide, Bernal concluded: either to turn away from posthuman possibilities that offend our values, or to adapt our values to our new powers and "into the service of the future which they will have to bring about".

n n 1932, Haldane was elected to the Royal Society (UK), and the following year he became Professor of Genetics at University College London. He continued to write widely in order to popularize science and socialism. Haldane was an active anti-fascist and worked to defend the Spanish Republic against the rise of Franco, but he left the Communist Party in 1950 owing to the influence that Trofim Lysenko (1898-1976) had on Soviet science, and the revelations about Josef Stalin's regime of terror. In 1957, Haldane emigrated to India, and directed the Orissa State Genetics and Biometry Laboratory until his death in 1964.

Shortly before his death, Haldane wrote a final essay, Biological Possibilities for the Human Species in the Next Ten Thousand Years, in which he expressed deep concerns about the threat of nuclear war and whether humanity has any future (Haldane, 1963). Having lived to see Stalinism and fascism, Haldane was no longer as convinced of the desirability of world government as a solution to conflict, noting that the prospect of "a tyrant world state is equally sinister". However, he noted that, "a few centuries of Stalinism or technocracy might be a cheap price to pay for the unification of mankind".

With or without a global state, Haldane hoped that peace and disarmament might still be possible, and that humanity would be able to take advantage of biological science to provide agricultural prosperity, eliminate 
disease and enhance human abilities. By mapping the range of extant human abilities, scientists could make the extraordinary abilities of the few-such as the dexterity of yogis-accessible to everyone. Haldane coined the term 'clone' and suggested that people with extraordinary abilities should be cloned. He also suggested that humans could acquire desirable animal traits through transgenic engineering.

In this last essay, Haldane also returned to the theme of posthuman evolution beyond Earth, and suggested that spacefaring humans could trade their useless legs for prehensile tails, and be adapted for atmospheric extremes and high radiation. Like Wells and Bernal, he noted that, "there will be a real prospect of our species dividing into two or more branches", but he believed it more likely that humans would become much more biologically and psychologically diverse, and more tolerant of our expanding polymorphism. "If the capacity for consciousness and control of physiological processes is prized by posterity, steps will probably be taken to make it commoner, and it may be that ten thousand years hence our descendants will differ from us not only in achievements but in capacities and aspirations."

$\mathrm{T}$ he Utopian biofuturism expressed in the writings of these British scientists, philosophers and authors is an inevitable product of the Enlightenmentthe projection of its narrative of progress through science and reason onto medicine and biology. For 300 years, Enlightenment partisans have been offering prospects for radical life extension, the elimination of disease and disability, cognitive enhancement and the control of mood as future prospects, only to be contested by sceptics from both inside and outside their camp. Religious conservatives criticize the possible destruction of moral order in these futurist narratives, whereas secular, left-wing pessimists fear that technological evolution will create a posthuman superclass, a dehumanizing insectile homogeneity or a hedonistic social stasis.

Yet, as we see in this British episode of the 1920s, the biofuturists-Wells, Haldane, Stapledon and Bernal-surely recognize the dystopian possibilities; indeed, they are often the first ones to give warnings about them. Yet they also recognize the risks if humanity stays the way it is, and the unlikelihood that human evolution has halted or will stop. Their appeal is not so much that we must become posthuman because of a teleological imperative, but rather that as we are becoming posthuman, we should strive for a flourishing form of posthumanity that fulfils our highest aspirations. To achieve the best possible future, the bio-optimists argued, we must enhance our moral sense and our capacity for social responsibility. This part of their admonition seems to be increasingly relevant today.

\section{REFERENCES}

Adams MB (2000) Last judgment: the visionary biology of J.B.S. Haldane. J Hist Biol 33: 457-491

Bernal JD (1929) The World, the Flesh \& the Devil: An Enquiry into the Future of the Three Enemies of the Rational Soul. London, UK: Kegan Paul, Trench, Trubner \& Co

Bernal JD (1939) Social Function of Science. London, UK: Routledge

Dyson F (1995) Daedalus after seventy years. In Haldane's Daedalus Revisited, KR Dronamraju (ed), pp 55-63. Oxford, UK: Oxford University Press

Green RL, Hooper W (1974) C.S. Lewis: A Biography. New York, NY, USA: Harcourt Brace Jovanovich

Haldane JBS (1924) Daedalus, or Science and the Future: A Paper Read to the Heretics, Cambridge on February 4th, 1923. London, UK: Kegan Paul, Trench, Trubner \& Co

Haldane JBS (1927) The last judgment, a scientist's vision of the future of man. In Possible Worlds and Other Essays, pp 287-312. London, UK: Chatto and Windus

Haldane JBS (1933) Science and Human Life. Manchester, NH, USA: Ayer

Haldane JBS (1963) Biological possibilities for the human species in the next ten thousand years. In Man and His Future: A Ciba Foundation Volume, Wolstenholme G (ed), pp 337-361. Boston, MA, USA: Little, Brown \& Co

Huxley A (1932) Brave New World. New York, NY, USA: Harper \& Row

Huxley J (1957) Transhumanism. In New Bottles for New Wine. London, UK: Chatto \& Windus

Lewis CS (1966) Of Other Worlds: Essays and Stories. New York, NY, USA: Harcourt Brace Jovanovich

Nicol C (2007) Brave New World at 75. New Atlantis 16: 41-54

Paul DB (2004) Genetic engineering and eugenics: the uses of history. In Is Human Nature Obsolete?: Genetics, Bioengineering, and the Future of the Human Condition, H Ballie, T Casey (eds), pp 123-152. Cambridge, MA, USA: MIT Press

Rubin CT (2005) Daedalus and Icarus revisited. New Atlantis 8: 73-91

Russell B (1924) Icarus, or The Future of Science. New York, NY, USA: EP Dutton \& Co

Stapledon O (1930) Last and First Men. London, UK: Methuen

Wells HG (1901) First Men in the Moon. London, UK: G. Newnes

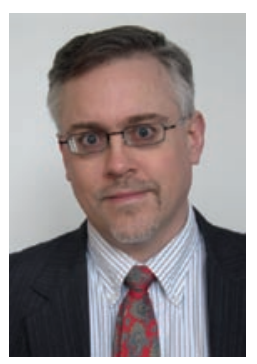

James J. Hughes is Executive Director of the Institute for Ethics and Emerging Technologies in Hartford, CT, USA.

E-mail: director@ieet.org

doi:10.1038/embor.2008.68 